\title{
Pulsed direct and constant direct currents in the pilocarpine iontophoresis sweat chloride test
}

\author{
Carla Cristina Souza Gomez ${ }^{1,2^{*}+}$, Maria de Fatima Servidoni ${ }^{1,2,3^{\dagger}}$, Fernando Augusto de Lima Marson ${ }^{1,2,4^{*} \dagger}$, \\ Paulo Jose Coelho Canavezi ${ }^{5}$, Adriana Mendes Vinagre ${ }^{1,2}$, Eduardo Tavares Costa ${ }^{5,6}$, Antonio Fernando Ribeiro ${ }^{1,2}$, \\ Maria Angela Gonçalves de Oliveira Ribeiro², Adyleia Aparecida Dalbo Contrera Toro ${ }^{1,2}$, Celia Regina Pavan ${ }^{3}$, \\ Michelle Vivine Sá dos Santos Rondon ${ }^{3}$, Sonia Leticia Silva Lorena ${ }^{3}$, Francisco Ubaldi Vieria Junior ${ }^{5,7}$ \\ and Jose Dirceu Ribeiro ${ }^{1,2^{*}}$
}

\begin{abstract}
Background: The classic sweat test (CST) is the golden standard for cystic fibrosis (CF) diagnosis. Then, our aim was compare the production and volume of sweat, and side effects caused by pulsed direct current (PDC) and constant direct current (CDC). To determine the optimal stimulation time (ST) for the sweat collection. To verify the PDC as CF diagnosis option.

Methods: Prospective study with cross-sectional experimental intervention. Experiment 1 (right arm): PDC and CDC. ST at $10 \mathrm{~min}$ and sweat collected at $30 \mathrm{~min}$. Currents of 0.5; 0.75; 1.0 and $1.5 \mathrm{~mA}$ and frequencies of 0, 200, 1,000 and 5,000 Hz applied. Experiment 2 (left arm): current of $1.0 \mathrm{~mA}$, ST at 5 and $10 \mathrm{~min}$ and sweat collected at 15 and 30 min with frequencies of 0; 200; 1,000 and 5,000 Hz applied Experiments 1 and 2 were performed with current density (CD) from 0.07 to $0.21 \mathrm{~mA} / \mathrm{cm}^{2}$. Experiment 3: PDC was used in typical CF patients with two CFTR mutations screened and or with CF diagnosis by rectal biopsy and patients with atypical CF.

Results: 48 subjects (79.16\% female) with average of $29.54 \pm 8.87$ years old were enrolled. There was no statistical difference between the interaction of frequency and current in the sweat weight $(p=0.7488)$. Individually, positive association was achieved between weight sweat and stimulation frequency $(p=0.0088)$; and current $(p=0.0025)$. The sweat production was higher for 10 min of stimulation $(p=0.0023)$. The sweat collection was better for 30 min $(p=0.0019)$. The skin impedance was not influenced by ST and sweat collection $(p>0.05)$. The current frequency was inversely associated with the skin impedance $(p<0.0001)$. The skin temperature measured before stimulation was higher than after $(p<0.0001)$. In Experiment 3 (29 subjects) the PDC showed better kappa index compared to CDC ( 0.9218 versus 0.5205 , respectively).

Conclusions: The performance of the CST with CDC and PDC with CD of 0.14 to $0.21 \mathrm{~mA} / \mathrm{cm}^{2}$ showed efficacy in steps of stimulation and collection of sweat, without side effects. The optimal stimulation time and sweat collection were, respectively, 10 and $30 \mathrm{~min}$.
\end{abstract}

Keywords: Constant direct current, Cystic fibrosis, lontophoresis, Pulsed direct current, Sweat test

\footnotetext{
*Correspondence: carlacg.gomez@gmail.com; fernandolimamarson@hotmail.com;

jdirceuribeiro@gmail.com

${ }^{\dagger}$ Equal contributors

'Departament of Pediatrics, Faculty of Medical Sciences, State University of

Campinas, 13083-887 Campinas, SP, Brazil

${ }^{2}$ Centre for Research in Pediatrics (CIPED), Faculty of Medical Sciences, State

University of Campinas, 13083-887 Campinas, SP, Brazil

Full list of author information is available at the end of the article
} 


\section{Background}

The first report of increased levels of sodium and chloride on sweat in cystic fibrosis (CF, MIM \#219700) patients was published in 1953 [1]. Later, Gibson and Cooke [2] described a method of cholinergic stimulation with pilocarpine iontophoresis on the skin to facilitate the dosage and stimulation of the sweat electrolytes. This method is known as the classic sweat test (CST), and still is considered the golden standard for CF diagnosis $[3,4]$.

In the sweat gland ducts, chloride ions (Cl-) are reabsorbed by the CFTR (cystic fibrosis transmembrane regulator) [5]. Then, in health subjects, the normal concentration of sweat chloride levels are minor than $30 \mathrm{mmol} / \mathrm{L}[6,7]$. CF patients show in the distal ducts of sweat gland, absence or defect of CFTR protein, and reduction of $\mathrm{Cl}$ - reabsorption $[8,9]$.

Two distinct CST confirms CF diagnosis when sweat $\mathrm{Cl}$ - levels are greater than $60 \mathrm{mmol} / \mathrm{L}$. The sweat test by European perspective is divided by ranges considering the following groups: minor than $30 \mathrm{mmol} / \mathrm{L}$ (normal range), 30 to $60 \mathrm{mmol} / \mathrm{L}$ (intermediate range), higher than $60 \mathrm{mmol} / \mathrm{L}[6,7,10]$.

The CST implementation presents many difficulties. It is divided into three stages: stimulation, collection and electrolytes measurement [11]. During the stimulation fase can occur: low amount of sweat production, difficulties to immobilize children, stress, burns, pain, hives, redness and skin irritation, when the current density (CD) is applied over than $0.5 \mathrm{~mA} / \mathrm{cm}^{2}$. Electric shock and skin injuries may occur when the metal electrode is in direct contact with the skin, in case of misuse. In collection stage can occur: contamination, sample evaporation and inadequate time in the sweat production. For electrolytes dosage the problems include a lack of specialized professional to perform the sweat analysis and variability of equipment brands for electrolytes measurement $[2,11,12]$.

Taking into account the difficulties in CST realization, to standardize the CST in Brazil has been a great problem. Sweat stimulation equipments are, principally, constructed by CF reference centers and have no authorization from the national health surveillance agency. Recently, the Brazilian government authorized the Macroduct ${ }^{\circ}$ (Wescor ${ }^{\circ}$, USA, Utah) system for the CST [13-15]. However, due to the difficulties in purchasing and maintaining the devices, few Brazilian laboratories have this equipment, with no standard use.

In the literature, the constant direct current (CDC) is used to induce the sweat by iontophoresis. There are reports on the efficiency in the substances delivery through the skin by pulsed direct current (PDC), without causing burning and discomfort risk when compared to CDC. On the other hand, some authors have found greater, smaller or equal efficacy between $\mathrm{CDC}$ and PDC for substances delivery into the skin by iontophoresis [16-19].
Sweat test made with gauze or filter paper use the minimum amount of $75 \mathrm{mg}$ of sweat (classical experiment by Gibson and Cooke), while the sweat collected by serpentine or plastic capillary tube is $15 \mu \mathrm{L}$. After collecting, sweat samples are sent to dosage the electrolytes concentration $[2,6,7,13]$.

The aim of the present study was to compare the sweat weight and side effects by PDC and CDC and determine the optimal stimulation time of sweat collection in healthy individuals. In addition, we checked PDC use for CF diagnosis in patients with and without confirmed CF diagnosis, who had previously performed CST with CDC.

\section{Methods}

Experimental study, with prospective cross-sectional intervention in subjects with and without CF disease.

For the CST, the sweat-inducing device developed by the Centre of Biomedical Engineering University was used. The iontophoresis device is portable, easy to use and able to select PDC and CDC, with triangular waveform, frequency from zero to $5,000 \mathrm{~Hz}$, maximum current of $5 \mathrm{~mA}$, software settings and data acquisition support, and two electrodes comprising 70\% copper and 30\% zinc with diameter of $30 \mathrm{~mm}$. The battery powered was used in the sweat test device. Sweat tests were performed with $0.5 \%$ pilocarpine (refrigerated when not in use).

The Research Ethics Committee of the State University of Campinas (\#80430/2012) approved the project. All subjects read and signed an informed consent.

The room temperature was stabilized at $25^{\circ} \mathrm{C}$ and the applied $C D$ was calculated according to the formula $\mathrm{P}=\mathrm{I} / \mathrm{S} ; \mathrm{P}=$ density, $\mathrm{I}=$ current and $\mathrm{S}=$ electrode area.

The variables gender, ethnicity, age and body mass index (BMI) were considered. The BMI calculation was performed by the formula: weight $(\mathrm{kg}) /$ height $^{2}(\mathrm{~m})$ [20].

Three sets of experiments were performed:

\section{Experiment 1: right arm of healthy subjects (randomly selected frequency and intensity of the current)}

Objective: to compare the sweat weight and impedance of the electrode assembly, gauze and skin between CDC and PDC. We used stimulation time of $10 \mathrm{~min}$ and sweat collection of $30 \mathrm{~min}$. We applied currents of $0.5 ; 0.75 ; 1.0$ and $1.5 \mathrm{~mA}$, frequency of 0, 200, 1,000 and 5,000 Hz. Data collection was done along six months.

\section{Experiment 2: left arm of healthy subjects (randomly selected stimulation time, collection time and current frequency)}

Objective: to compare the sweat weight and impedance of the electrode assembly, gauze and skin with different stimulation and collection times. Were applied fixed current of $1 \mathrm{~mA}$ in the tests. Stimulation time of five and 
$10 \mathrm{~min}$, and collection at 15 and $30 \mathrm{~min}$ at frequencies of 0, 200, 1,000 and 5,000 Hz. Data collection was done along six months.

\section{Experiment 3: right arm of patients with classical and} atypical CF (PDC current of $1 \mathrm{~mA}$, frequency of $1,000 \mathrm{~Hz}$, stimulation time of $10 \mathrm{~min}$ and collection time of $30 \mathrm{~min}$ ) Objective: to compare the sweat weight and chloride levels by PDC and CDC. Compare the CF diagnosis by CST (considering the PDC and CDC) with the results of rectal biopsy [21] and CFTR mutations. Data collection was done during two days for all subjects enrolled. All the subjects enrolled are attended in CF reference center considering the clinical symptoms and comorbidities related with CF disease. The subjects performed the CST - CDC before the study, and PDC during the study. The data was compare with CFTR mutations and CFTR expression and function (determined by rectal biopsies).

The CST was performed in three steps: stimulation, collection and measurement, according to Gibson and Cooke [2], with a distance of five $\mathrm{cm}$ between the electrodes.

We evaluated the discomfort in the first, fifth and last minute by the visual analog scale (VAS) (Additional file 1) [22].

The impedance of the set composed by electrode, gauze and skin during the stimulation time was calculated by Ohm's law $\left[\mathrm{Z}=\mathrm{V}_{\mathrm{RMS}} / \mathrm{I}_{\mathrm{RMS}}(\Omega)\right]$; $\mathrm{Z}=$ impedance $(\Omega)$; $\mathrm{V}_{\mathrm{RMS}}=$ voltage measured by $\mathrm{RMS}(\mathrm{V}) ; \mathrm{I}_{\mathrm{RMS}}=$ current measured by RMS (A).

To collect the sweat were used two filter paper of $17.5 \mathrm{~cm}^{2}$ covered with plastic and bandage crepe filter. In classical Gibson and Cooke test, the $75 \mathrm{mg}$ sweat criteria was considered, being $1 \mathrm{~g}$ (sweat) $/ \mathrm{m}^{2}$ (sweat collection area)/min (collection time) in a area of $5.5 \mathrm{~cm}$ diameter filter paper. To simulate this value, a sweat weight of $54 \mathrm{mg}$ was considered in our data.

Manual titration and flame fotometometria were used to analyze chloride and sodium concentration in $\mathrm{mEq} / \mathrm{L}$, respectively [2,6,7]. Quality controls (positive cases of sweat tests and health subjects) were used to perform the chloride and sodium dosage.

Each subject performed Experiment 1 and Experiment 2 at the same time. The Experiment 3 was performed after the conclusion of the Experiments 1 and 2 .

\section{Statistical analysis}

SAS (Statistical Analysis System) for Windows, vs 9.2. (SAS Institute Inc, 2002-2008, Cary, NC, USA) was used for data analysis. Graphs were designed using SPSS (Statistical Package for the Social Sciences) vs 22.0 (IBM ${ }^{\oplus}$, Armonk, NY, USA) and Medcalc vs 13.2.2 (MedCalc Software, Acacialaan 22, B-8400 Ostend, Belgium).
Numerical variables are shown by position and dispersion measures. Analysis of variance (ANOVA) for repeated measures was used to compare data parameters. We applied the transformation of posts due to the lack of normal distribution.

Spearman's correlation was applied to correlate the chloride values and sweat weight for CDC and PDC of CF patients, atypical CF patients, and healthy subjects. Kappa index was performed to measure the concordance among data.

The significance level was set at $\alpha=0.05$ and $\beta=0.08$. Results were presented in tables and graphs.

\section{Results}

The study enrolled 77 subjects, 48 healthy individuals (79.16\% female) with an average of $29.54 \pm 8.87$ years and 29 patients, with classical and atypical CF, with an average age of $24.37 \pm 12.11$ years. Table 1 shows the features from the studied population including the experiments 1, 2 and 3. CFTR mutation frequency and mutation characterization are described, respectively, in the Additional files 2 and 3.

\section{Experiment 1 - testing intensity and frequency of the current for sweat test}

There was no statistical difference between the interaction of frequency and current for the sweat weight $(\mathrm{p}=0.7488)$ (Table 2, Figure 1).

Considering the CST by Gibson and Cooke, 16.7\% $(3 / 24)$ of the subjects in the Experiment 1 had no

Table 1 Clinical characterization of subjects enrolled in the experiments 1, 2 and 3

\begin{tabular}{lcc}
\hline Variable & Sample size & Distribution \\
\hline $\begin{array}{l}\text { Experiment } 1 \text { and } \\
\text { 2 subjects }\end{array}$ & & \\
Sex (masculine) & 48 & $18 / 48(37.5 \%)$ \\
Etnicity (Caucasian) & 48 & $35 / 48(72.9 \%)$ \\
Age $^{*}$ & 48 & $29.54 \pm 6.51 ; 27(20-55)$ \\
Height* $^{*}$ & 48 & $167.92 \pm 8.74 ; 166(150-191)$ \\
Weight* & 48 & $67.21 \pm 9.77 ; 65(50-95)$ \\
Body mass index* & 48 & $23.83 \pm 2.56 ; 23.22(18.14-34.48)$ \\
Experiment 3 & & \\
subjects & & $10 / 29(34.5 \%)$ \\
Sex (masculine) & 29 & $25 / 29(86.2 \%)$ \\
Etnicity (Caucasian) & 29 & $24.37 \pm 12.106 ; 21(6-46)$ \\
Age* & 29 & $1.56 \pm 0.154 ; 1.58(1.22-1.87)$ \\
Height* & 29 & $50.078 \pm 13.81 ; 52(26.8-76.6)$ \\
Weight* & 29 & $29.21 \pm 3.60 ; 19.71(13.20-29.65)$ \\
Body mass index* & 29 &
\end{tabular}

*Mean \pm standard deviation; median (minor and major values). 
Table 2 Sweat weight $(\mathrm{mg})$ at different frequencies and current

\begin{tabular}{lcccc}
\hline Frequency (Hz) $^{*}$ & \multicolumn{4}{c}{ Current $^{(\mathbf{m A})^{\#}}$} \\
\cline { 2 - 5 } & $\mathbf{0 . 5}$ & $\mathbf{0 . 7 5}$ & $\mathbf{1}$ & $\mathbf{1 . 5}$ \\
\hline $0(\mathrm{CDC})$ & $167 \pm 5.9$ & $173 \pm 12.2$ & $236 \pm 3.6$ & $328 \pm 11.8$ \\
200 & $78 \pm 2.0$ & $91 \pm 3.2$ & $189 \pm 5.5$ & $150 \pm 4.2$ \\
1000 & $146 \pm 8$ & $254 \pm 11.1$ & $300 \pm 13.7$ & $226 \pm 16.6$ \\
5000 & $136 \pm 3.2$ & $125 \pm 1.2$ & $221 \pm 9.0$ & $212 \pm 5.7$ \\
\hline
\end{tabular}

$\mathrm{CDC}$, constant direct current; $\mathrm{Hz}$, Hertz, $\mathrm{mA}$, milliampere. *For the frequency analysis and sweat weight, $\mathrm{p}$-value $=0.0088 ;{ }^{*}$ For the current and sweat weight, $p$-value $=0.0025$; for interaction between current, frequency and sweat weight, $\mathrm{p}$-value $=0.7488$.

sufficient sweat weight $(<75 \mathrm{mg}$ ) for low frequency versus $4.2 \%(1 / 24)$ for high frequencies, but no significant association was achieved $(\mathrm{p}=0.348)$. However, considering the $54 \mathrm{mg}$ sweat criteria in our data, all the subjects sweated correctly to perform the sweat test.

There was association from sweat weight with current frequency ( $\mathrm{p}=0.0088$, Figure $1 \mathrm{~b})$ and with current intensity applied $(p=0.0025$, Figure $1 \mathrm{a})$.
Experiment 2 - testing stimulation time, collection time and the frequency of the current

High sweat production occurred with $10 \mathrm{~min}$ of stimulation compared to $5 \mathrm{~min}(\mathrm{p}=0.0023)$, and $41.7 \%(10 / 24)$ of subjects had insufficient sweat weight $(<54 \mathrm{mg})$ in $5 \mathrm{~min}$ versus $4.2 \%(1 / 24)$ for $10 \mathrm{~min}(\mathrm{p}=0.002)$.

The collection time of 30 min allowed greater sweat weight than $15 \mathrm{~min}(\mathrm{p}=0.0019)$ (Table 3, Figure 2), and $37.58 \%(9 / 24)$ of subjects had insufficient sweat weight $(<54 \mathrm{mg})$ in $15 \mathrm{~min}$ versus $8.3 \%(2 / 24)$ for $30 \min (\mathrm{p}=0.018)$.

The skin impedance was not influenced by the time of sweat stimulation $(\mathrm{p}=0.2433)$, and sweat collection $(p=0.2697)$. There was no influence of interaction between stimulation and collection time $(\mathrm{p}=0.1204)$.

The current frequency was associated inversely with skin impedance $(\mathrm{p}<0.0001)$. Moreover, the current frequency showed no association with the collection time $(\mathrm{p}=0.7578)$, as well with the stimulation time $(\mathrm{p}=0.5898)$. There was no association between stimulation and collection time $(\mathrm{p}=0.9320)$ (Tables 4 and 5).

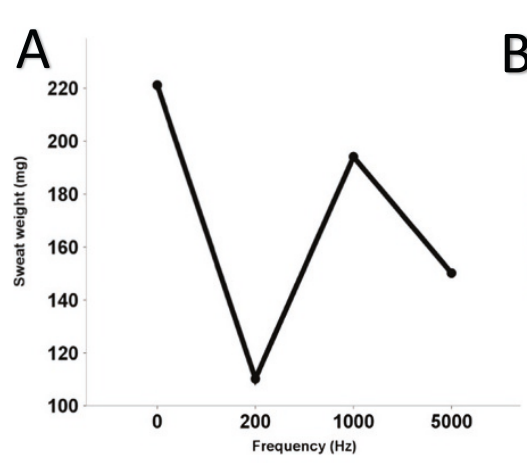

B
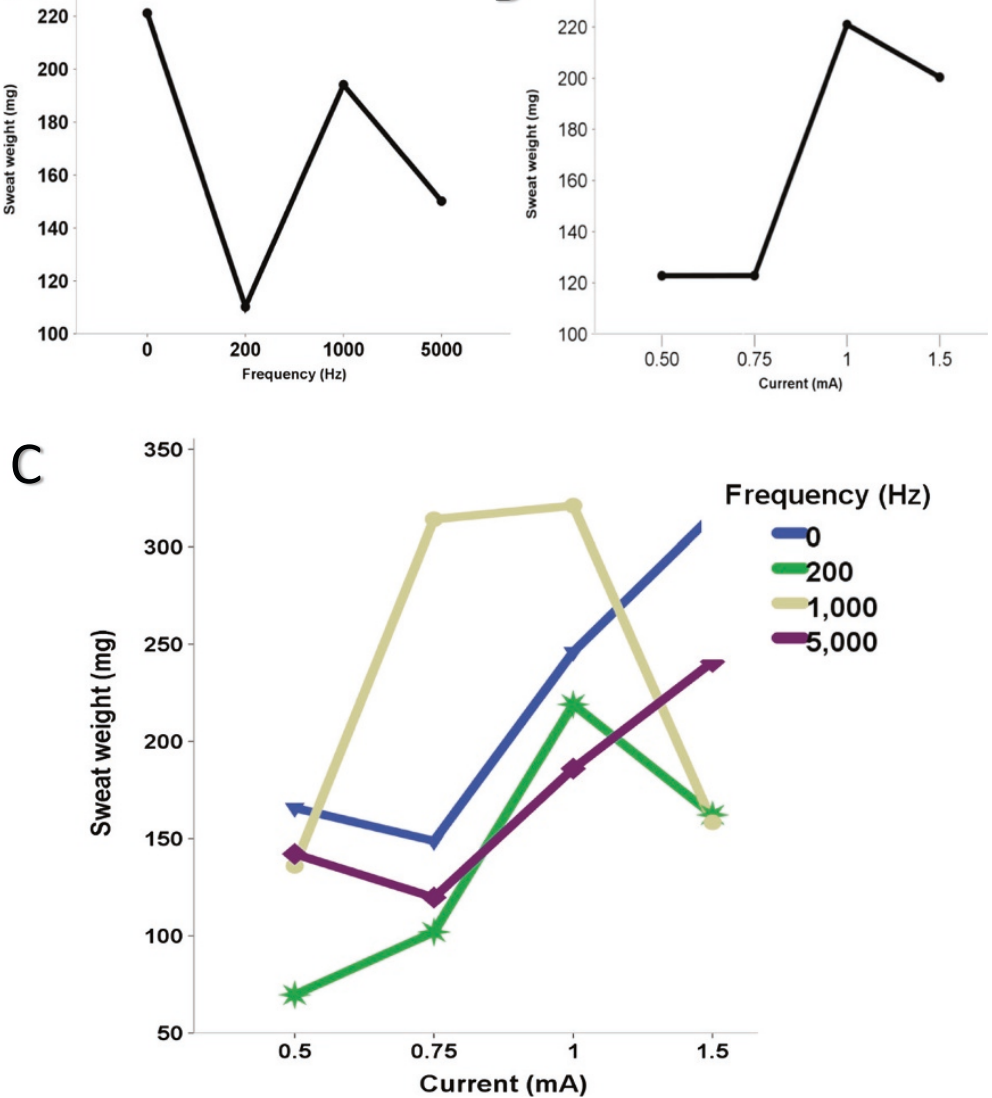

Figure 1 Association with the sweat weight, current and frequency. A. Current values and sweat weight $(p=0.0088)$. B. Frequency values and sweat weight $(p=0.0025)$. C. Interaction among current, frequency and sweat weight $(p=0.7488)$. 
Table 3 Sweat weight (mg) for frequencies and stimulation and collection time of sweat, with fixed current of $1 \mathrm{~mA}$

\begin{tabular}{lcccc}
\hline $\begin{array}{l}\text { Frequency } \\
\text { (Hz) }\end{array}$ & \multicolumn{4}{c}{ Stimulation Time $\mathbf{x}$ time of collection of the sweat ${ }^{*}$} \\
\cline { 2 - 5 } & $10 \times 30$ & $10 \times 15$ & $5 \times 30$ & $5 \times 15$ \\
\hline $0(C D C)$ & $160 \pm 5.1$ & $76 \pm 4.8$ & $18 \pm 0.204$ & $41 \pm 0.9$ \\
200 & $137 \pm 3.1$ & $118 \pm 14.4$ & $147 \pm 0.04$ & $77 \pm 3.9$ \\
1000 & $222 \pm 7.4$ & $138 \pm 7.0$ & $83 \pm 0.09$ & $80 \pm 4.9$ \\
5000 & $267 \pm 7.3$ & $164 \pm 8.8$ & $111 \pm 0.03$ & $69 \pm 6.3$ \\
\hline
\end{tabular}

$\mathrm{CDC}$, constant direct current; $\mathrm{Hz}, \mathrm{Hertz}, \mathrm{mA}$, milliampere. * In the analysis considering stimulation time, $\mathrm{p}$-value $=0.0023(10>5 \mathrm{~min}) ;{ }^{\#} \mathrm{In}$ the analysis considering the collection time, $p$-value $=0.0019(30>15 \mathrm{~min})$. For frequency $(p=0.4672)$, frequency + stimulation time $(p=0.3046)$, frequency + collection time $(p=0.6723)$, time of stimulus + collection time $(p=0.7131)$ and frequency + collection time + stimulus time $(p=0.7322)$, there was no statistical association.
For Experiments 1 and 2, discomfort scale was low and did not allow comparison between the currents and frequencies, as well, for induction and collection time of sweat. All controls showed normal levels of chloride and sodium in sweat test for Experiments 1 and 2. Skin temperature before stimulation was higher than after ( $p<0.001$ in both cases) (Tables 6 and 7). The layer of fat in the skin assessed by BMI showed no statistical difference for different frequencies and intensities of the currents, as well as different stimulation and collection times ( $p>0.05)$. The CD ranged from 0.07 to $0.21 \mathrm{~mA} / \mathrm{cm}^{2}$ (Table 8 ).

\section{Experiment 3 - classical and atypical CF}

Both the CDC $(\mathrm{p}=0.006)$ and PDC $(\mathrm{p}<0.001)$ showed values consistent with the results of rectal biopsy and
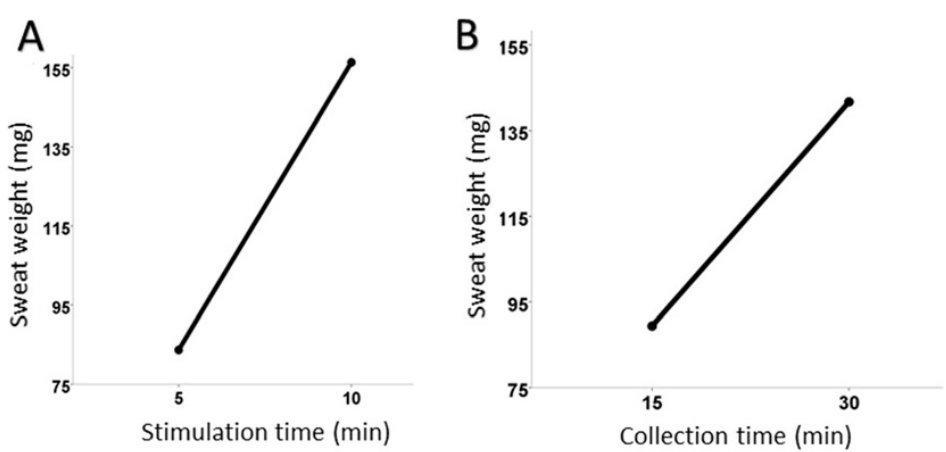

C

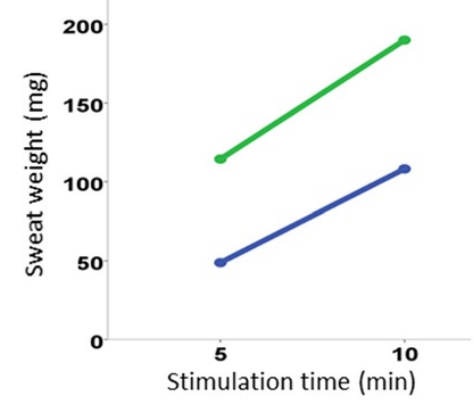

Collection time $(\mathrm{min})$

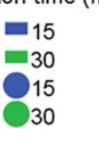

D

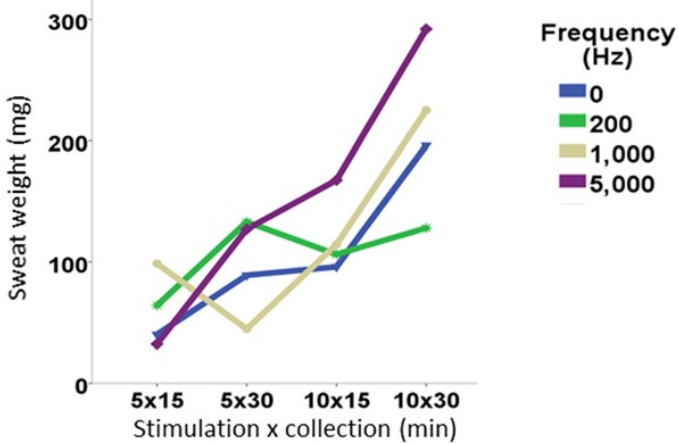

Figure 2 Association of sweat weight with the stimulation and collection time and frequency. A. Stimulation time and sweat weight $(p=0.5898)$. B. Collection time and sweat weight $(p=0.9320)$. C. Stimulation and collection time and sweat weight $(p=0.1204)$. D. Stimulation and collection time, frequency and sweat weight $(p=0.7578)$. 
Table 4 Impedance data (in Ohm) for frequencies and currents, with a fixed time of 10 min for stimulation and 30 min for collection

\begin{tabular}{lccrr}
\hline Frequency $(\mathbf{H z})^{*}$ & \multicolumn{4}{c}{${\text { Current }(\mathbf{m A})^{\#}}^{\#}$} \\
\cline { 2 - 5 } & $\mathbf{0 . 5}$ & $\mathbf{0 . 7 5}$ & $\mathbf{1}$ & $\mathbf{1 . 5}$ \\
\hline $0(\mathrm{CDC})$ & $11303.4 \pm 5487.4$ & $11339.3 \pm 7507.5$ & $8178.2 \pm 2004.9$ & $5685.5 \pm 838.5$ \\
200 & $8615.9 \pm 4763.1$ & $6086.4 \pm 1278.4$ & $5995.3 \pm 1592.9$ & $4727.6 \pm 562.7$ \\
1000 & $6787.3 \pm 1997.8$ & $4387.7 \pm 703.0$ & $4198.1 \pm 2125.4$ & $2975.2 \pm 216.2$ \\
5000 & $6221.3 \pm 1962.3$ & $4480.2 \pm 450.5$ & $4462.3 \pm 1848.2$ & $3226.1 \pm 159.6$ \\
\hline
\end{tabular}

$\mathrm{CDC}$, constant direct current; $\mathrm{Hz}$, Hertz, $\mathrm{mA}$, milliampere. ${ }^{*}$ In the analysis considering the frequency in relation to the impedance, $\mathrm{p}$-value $=0.0007 ;{ }^{\#} \mathrm{In}$ the analysis considering the current in relation to the impedance, $\mathrm{p}$-value $=0.0003$; for interaction between current and frequency in relation to the impedance, $\mathrm{p}$-value $=0.9871$.

CFTR mutations. However, the Kappa index was higher for PDC (Table 9). PDC showed correlation on chloride levels with $\mathrm{CDC}$ (Figure 3A); the same was not true for the sweat weight (Figure $3 \mathrm{~B}$ ).

\section{Discussion}

Although CST is considered the golden standard for the CF diagnosis [3,4,6,23-25], studies have reported difficulties in performing the test, especially for sweat collection and electrolyte measurement [26-28]. The sweat stimulation, which is the first step for CST, had few studies since its implementation and standardization, in 1959, by Gibson and Cooke [2], and was enhanced in 1983 by the Webster Sweat inducer system [29], along with the Wescor Macroduct kit [14,30]. Although the benefits of iontophoresis have been exploited for other purposes, the CST has not been changed.

Advantages of the PDC use for the iontophoresis method over CDC has been demonstrated in studies with transdermic delivery of substances [18,31-34]. Most studies showed greater efficacy of the PDC for delivery of substances into the skin $[2,29]$.

PDC iontophoresisis is less uncomfortable than the CDC. The depolarization occurs between pulses, preventing epidermal irritation $[33,35,36]$. In the present study, in healthy adults, both PDC and CDC were not annoying. This finding may be due to the use of low $C D$ used for the PDC and CDC.

The CDC can cause permanent polarization of the skin during the stimulation, which affects the efficiency of substance delivery proportionally to the time of application of the impedance. This fact can be minimized by the use of PDC, which is delivered periodically [37,38]. During the phase without stimulation, the skin becomes depolarized and returns to its initial polarization. However, Bagniefski and Burnett (1990) showed that greater depolarization of the skin may decrease the efficiency of drug delivery, if the frequency is high [18]. In this study, frequencies of 1,000 to $5,000 \mathrm{~Hz}$ were more effective for pilocarpine delivery and induction of skin perspiration for the CST compared to lower frequencies of zero to $200 \mathrm{~Hz}$. In our study, all subjects in the Experiment 1 had sufficient sweat weight $(<54 \mathrm{mg})$ for low and high frequencies.

Studies with PDC have shown that the waveform influence on the permeation of the substance into the skin. Chien and Chen [39] had studied the absorption of luteinizing- hormone-releasing hormone (LHRH) using CDC and PDC with different waveforms. Sinusoidal and rectangular shapes waves were equal to $\mathrm{CDC}$ in the flux of hormone delivery, but the flow for triangular waves was lower than the CDC. Chien et al. [40] showed that the flow of drug delivery was efficient for sinusoidal, trapezoidal and rectangular waves. Hirvonen [41] reported that the amino acids permeability into skin by $\mathrm{CD}$ of $0.5 \mathrm{~mA} / \mathrm{cm}^{2}$ and frequency of $2.5 \mathrm{kHz}$ were equal of rectangular and sinusial waves. Kanebako [42] showed that the permeability of the drug tested was better with the use of PDC with frequencies below $100 \mathrm{~Hz}$ and rectangular wave.

Table 5 Impedance (in $\mathrm{Ohm}$ ) with frequency data for each diade of stimulation and collection time, with fixed current of $1 \mathrm{~mA}$

\begin{tabular}{lcccc}
\hline Frequency $\mathbf{H z})$ & \multicolumn{4}{c}{ Stimulation time* collection time on sweat test $^{\#}$} \\
\cline { 2 - 5 } & $\mathbf{1 0 \times \mathbf { 3 0 }}$ & $\mathbf{1 0} \times \mathbf{1 5}$ & $\mathbf{5} \times \mathbf{3 0}$ & $\mathbf{5} \times \mathbf{1 5}$ \\
\hline $0(\mathrm{CDC})$ & $7656.7 \pm 363.1$ & $7527.3 \pm 3199.3$ & $9856.1 \pm 2517.7$ & $13030.4 \pm 2641.0$ \\
200 & $6765.5 \pm 1271.5$ & $5500.3 \pm 697.5$ & $5681.9 \pm 1075.2$ & $5795.6 \pm 1457.4$ \\
1000 & $4822.4 \pm 1280.9$ & $3895.6 \pm 117.2$ & $4965.8 \pm 613.7$ & $4356.3 \pm 882.2$ \\
5000 & $5317.9 \pm 831.4$ & $5330.1 \pm 3088.6$ & $5376.0 \pm 1691.7$ & $5873.9 \pm 74.6$ \\
\hline
\end{tabular}

CDC, constant direct current; $\mathrm{Hz}, \mathrm{Hertz}, \mathrm{mA}$, milliampere. ${ }^{*}$ In the analysis considering time of stimulation, $\mathrm{p}$-value $=0.2433$; ${ }^{\#} \mathrm{In}$ the analysis considering the time of collection, $p$-value $=0.2697$. There was no statistical association for frequency $(p<0.0001)$, frequency + stimulation time $(p=0.5898)$, frequency + collection time $(p=0.7578)$, time of stimulus + collection time $(p=0.1204)$ and frequency + stimulus time + collection time $(p=0.9320)$. 
Table 6 Frequency and current in relation to the skin temperature

\begin{tabular}{|c|c|c|c|c|}
\hline Frequency $(\mathrm{Hz})^{*}$ & Current ${ }^{\#}$ & Skin temperature & Mean & $\begin{array}{l}\text { Standard } \\
\text { deviation }\end{array}$ \\
\hline \multirow[t]{8}{*}{0 (CDC) } & 0.5 & Before & 30.9 & 0.4 \\
\hline & & After & 29.3 & 1.2 \\
\hline & 0.75 & Before & 31.0 & 0.3 \\
\hline & & After & 30.6 & 1.5 \\
\hline & 1 & Before & 30.5 & 0.9 \\
\hline & & After & 30.4 & 0.7 \\
\hline & 1.5 & Before & 31.0 & 0.3 \\
\hline & & After & 30.6 & 1.5 \\
\hline \multirow[t]{8}{*}{200} & 0.5 & Before & 30.9 & 1.2 \\
\hline & & After & 29.6 & 0.4 \\
\hline & 0.75 & Before & 31.5 & 3.2 \\
\hline & & After & 29.6 & 1.4 \\
\hline & 1 & Before & 31.6 & 2.3 \\
\hline & & After & 31.2 & 1.8 \\
\hline & 1.5 & Before & 29.4 & 1.8 \\
\hline & & After & 28.0 & 1.4 \\
\hline \multirow[t]{8}{*}{1,000} & 0.5 & Before & 31.8 & 0.9 \\
\hline & & After & 30.7 & 0.1 \\
\hline & 0.75 & Before & 31.3 & 0.8 \\
\hline & & After & 30.1 & 0.8 \\
\hline & 1 & Before & 30.4 & 2.3 \\
\hline & & After & 31.3 & 1.0 \\
\hline & 1.5 & Before & 30.8 & 1.0 \\
\hline & & After & 31.1 & 2.0 \\
\hline \multirow[t]{8}{*}{5,000} & 0.5 & Before & 31.4 & 1.6 \\
\hline & & After & 29.3 & 1.4 \\
\hline & 0.75 & Before & 30.2 & 0.8 \\
\hline & & After & 29.9 & 0.7 \\
\hline & 1 & Before & 31.6 & 2.1 \\
\hline & & After & 30.3 & 2.1 \\
\hline & 1.5 & Before & 32.8 & 1.5 \\
\hline & & After & 31.4 & 0.5 \\
\hline
\end{tabular}

$\mathrm{CDC}$, constant direct current; $\mathrm{Hz}, \mathrm{Hertz}, \mathrm{mA}$, milliampere. *In the analysis considering the frequency in relation to skin temperature, $p$-value $=0.4102$; \# In the analysis considering the current in relation to skin temperature, $\mathrm{p}$-value $=0.5361$; for interaction between current and frequency in relation to skin temperature, $\mathrm{p}$-value $=0.0884$. The skin temperature before the experiment was higher than after, $\mathrm{p}$-value $<0.0001$.

The square waveform was tested by Panzade et al. [38] for granisetron penetration by iontophoresis, and showed better results in CDC. However, the PDC was considered less uncomfortable to the skin.

Unlike previous studies, we use the PDC with triangular waveform and lower current values, which resulted in adequate sweat weight. In this case, the PDC was a
Table 7 Skin temperature considering frequency, time of stimulation and collection time, with fixed current of $1 \mathrm{~mA}$

\begin{tabular}{|c|c|c|c|c|c|}
\hline $\begin{array}{l}\text { Frequency } \\
(\mathrm{Hz})^{*, \#}\end{array}$ & $\begin{array}{c}\text { Time of } \\
\text { stimulation }\end{array}$ & $\begin{array}{l}\text { Time of } \\
\text { collection }\end{array}$ & $\begin{array}{c}\text { Skin } \\
\text { temperature }\end{array}$ & Mean & $\begin{array}{l}\text { Standard } \\
\text { deviation }\end{array}$ \\
\hline \multirow[t]{8}{*}{0 (CDC) } & $10 \mathrm{~min}$ & $30 \mathrm{~min}$ & Before & 30.7 & 0.7 \\
\hline & & & After & 30.2 & 0.8 \\
\hline & & $15 \mathrm{~min}$ & Before & 31.1 & 2.3 \\
\hline & & & After & 29.2 & 1.6 \\
\hline & $5 \mathrm{~min}$ & $30 \mathrm{~min}$ & Before & 29.6 & 1.4 \\
\hline & & & After & 29.3 & 1.4 \\
\hline & & $15 \mathrm{~min}$ & Before & 31.6 & 1.7 \\
\hline & & & After & 29.2 & 2.1 \\
\hline \multirow[t]{8}{*}{200} & $10 \mathrm{~min}$ & $30 \mathrm{~min}$ & Before & 31.3 & 1.1 \\
\hline & & & After & 30.4 & 0.9 \\
\hline & & $15 \mathrm{~min}$ & Before & 32.2 & 1.3 \\
\hline & & & After & 31.3 & 2.3 \\
\hline & $5 \mathrm{~min}$ & $30 \mathrm{~min}$ & Before & 32.3 & 1.1 \\
\hline & & & After & 30.5 & 1.0 \\
\hline & & $15 \mathrm{~min}$ & Before & 29.3 & 2.1 \\
\hline & & & After & 28.2 & 3.5 \\
\hline \multirow[t]{8}{*}{1,000} & $10 \mathrm{~min}$ & $30 \mathrm{~min}$ & Before & 29.8 & 2.1 \\
\hline & & & After & 30.1 & 1.6 \\
\hline & & $15 \mathrm{~min}$ & Before & 31.6 & 2.0 \\
\hline & & & After & 30.9 & 1.6 \\
\hline & $5 \mathrm{~min}$ & $30 \mathrm{~min}$ & Before & 31.3 & 1.3 \\
\hline & & & After & 29.6 & 0.5 \\
\hline & & $15 \mathrm{~min}$ & Before & 31.9 & 2.1 \\
\hline & & & After & 30.2 & 1.6 \\
\hline \multirow[t]{8}{*}{5,000} & $10 \mathrm{~min}$ & $30 \mathrm{~min}$ & Before & 31.2 & 2.8 \\
\hline & & & After & 30.8 & 2.2 \\
\hline & & $15 \mathrm{~min}$ & Before & 33.2 & 3.0 \\
\hline & & & After & 30.9 & 2.8 \\
\hline & $5 \mathrm{~min}$ & $30 \mathrm{~min}$ & Before & 29.9 & 0.9 \\
\hline & & & After & 29.1 & 0.3 \\
\hline & & $15 \mathrm{~min}$ & Before & 29.9 & 3.1 \\
\hline & & & After & 29.2 & 2.2 \\
\hline
\end{tabular}

$\mathrm{CDC}$, constant direct current; $\mathrm{Hz}$, Hertz; mA, milliampere. *In the analysis considering the frequency in relation to skin temperature with the time of stimulation, $\mathrm{p}$-value $=0.4688$; ${ }^{\#}$ In the analysis considering the frequency in relation to skin temperature and collection time, $p$-value $=0.5770$. For interaction between frequency + stimulation time + collection time, $p$-value $=0.4682$. The skin temperature was significant higher before the sweat test than after, p-value $<0.0001$.

useful procedure to stimulate sweating. This finding should bring significant benefits, especially for younger children.

The substance penetration into the skin depends on the time for the applied current in iontophoresis [43]. 
Table 8 Current densities (electrode with $3 \mathrm{~cm}$ of diameter)

\begin{tabular}{lcc}
\hline Current $(\mathbf{m A})$ & $\begin{array}{c}\text { Current density } \\
\left(\mathbf{m A} / \mathbf{c m}^{2}\right)\end{array}$ & $\begin{array}{c}\text { \% volume of sweat } \\
\text { above } \mathbf{5 4} \mathbf{~ m g}^{*}\end{array}$ \\
\hline 0.5 & 0.07 & $12 / 12(100 \%)$ \\
0.75 & 0.12 & $12 / 12(100 \%)$ \\
1.0 & 0.14 & $12 / 12(100 \%)$ \\
1.5 & 0.21 & $12 / 12(100 \%)$
\end{tabular}

*The adequate sweat rate was considered for an area practically of $18 \mathrm{~cm}^{2}$ and $30 \mathrm{~min}$ of sweat stimulation. For the classical Gibson \& Cooke test, the area considered was related of a $5.5 \mathrm{~cm}$ diameter filter paper with $30 \mathrm{~min}$ of stimulation, and the $75 \mathrm{mg}$ criteria was used as the gold standard for the sweat.

Recent consensus on CST suggested that the stimulation time of $5 \mathrm{~min}$ is capable to stimulate sweating $[6,7,13,44]$. In our experiments, $10 \mathrm{~min}$ of stimulation was able to induce sweat levels greater than $54 \mathrm{mg}$, which was better than $5 \mathrm{~min}$. This fact is consistent with the first study inducing sweat iontophoresis [2]. In the present study, Experiment 2 showed 41.7\% (10/24) of subjects with insufficient sweat weight $(<54 \mathrm{mg})$ for stimulation time of $5 \mathrm{~min}$ and $4.2 \%(1 / 24)$ for $10 \mathrm{~min}(\mathrm{p}=0.002)$. In this case, the pilocarpine amount increased with the time of stimulation.

It is well known that sweat is not to be collected longer than $30 \mathrm{~min}$ and not less than $20 \mathrm{~min}[7,45]$. In the present study, the greatest weight in sweat occurred with $30 \mathrm{~min}$ of collection, with CD of 0.14 and $0.21 \mathrm{~mA} / \mathrm{cm}^{2}$.

Another important aspect related with the sweat test is the CD. Wrong CD calculation can cause risk of skin irritation and burns, therefore the maximum $\mathrm{CD}$ tolerability for the human skin is of $0.5 \mathrm{~mA} / \mathrm{cm}^{2}$ $[37,38,46,47]$. If the CD increases, the flow also increases, and consecutively the substance delivery. In the study of Panzade et al. [38], CDC proved to be 3.8 times higher for substance delivery compared to PDC. Then, the increase in $\mathrm{CD}$ causes an increase in transport of the drug through the pores of the skin.

In studies that induce sweat with pilocarpine it is not possible to identify the values of $\mathrm{CD}$. Two guideline suggested 0.16 to $0.24 \mathrm{~mA} / \mathrm{cm}^{2}$ as suitable CDs to CST $[44,48]$. In our study, the CDs between 0.14 to $0.21 \mathrm{~mA} / \mathrm{cm}^{2}$ were efficient for pilocarpine delivery into the skin by iontophoresis, inducing stimulation of the sweat in $100 \%$ of subjects with stimulation time of $10 \mathrm{~min}$ and $30 \mathrm{~min}$ for collection.

One of the disadvantages of substance delivery into skin by iontophoresis is the risk of shocks and burns due to the exposure of an electric current in the skin for long periods, overdose, lesions at the site of application, alternation of the $\mathrm{pH}$ and high current intensities $[49,50]$.

In our study, no subject had significant side effects, especially due to the low DC used, and indicating great safety.

The skin has relatively high impedance, which is mainly associated with the stratum corneum [45,51]. During the iontophoresis, skin resistance decreases and ion concentration increases in stratum corneum, allowing the substance delivery during electric current stimulation. At the end of the current flow, the ion concentration in the skin returns to physiological levels [52]. There is no evidence that the current amplitude and stimulation time are associated with temporary decrease in impedance, or with reduction in skin protection [53]. In the present study, with the stimulation times of 5 and $10 \mathrm{~min}$, no differences in the impedance of the electrode, gauze and skin system were observed.

Bioelectric properties of the skin allow the application of various forms of electric current. The opposition offered by the biological tissue is called impedance present in inter- and extracellular fluid, and the capacitive reactance of cell membranes. To occur the absorption of substances through the skin, the electrical current must overcome the impedance imposed on their flow and reach the target tissue with sufficient intensity [54,55]. Adipose tissue is bad conductor of electrical current, causing an increase in impedance. Although some studies have reported that the frequency variation would not influence the decrease in skin impedance $[18,42,56]$, Chien et al.

Table 9 Sweat test diagnosis by constant direct and pulsed direct currents taking into account cystic fibrosis diagnosis by other methods

\begin{tabular}{|c|c|c|c|c|c|c|c|c|}
\hline \multirow[t]{2}{*}{ Sweat test } & \multirow[t]{2}{*}{ Groups } & \multicolumn{2}{|c|}{ CF diagnosis* } & \multirow[t]{2}{*}{ Total } & \multirow{2}{*}{$\begin{array}{c}\mathrm{p}- \\
\text { value }\end{array}$} & \multirow{2}{*}{$\begin{array}{c}\text { Cohen's Kappa } \\
\text { index }\end{array}$} & \multirow{2}{*}{$\begin{array}{l}\text { Standard } \\
\text { error }\end{array}$} & \multirow[t]{2}{*}{ Agreement } \\
\hline & & Typical CF & Atypical CF & & & & & \\
\hline \multirow[t]{2}{*}{ Constant direct current } & Typical CF & 19 & 5 & 24 & 0.006 & 0.5205 & 0.1658 & Moderate \\
\hline & Atypical CF & 0 & 4 & 4 & & & & \\
\hline Total & & 19 & 9 & 28 & & & & \\
\hline \multirow[t]{2}{*}{ Pulsed direct current } & Typical CF & 19 & 1 & 20 & $<0.001$ & 0.9218 & 0.1851 & Almost perfect \\
\hline & Atypical CF & 0 & 9 & 9 & & & & \\
\hline Total & & 19 & 10 & 29 & & & & \\
\hline
\end{tabular}

*CF diagnosis was performed by CFTR mutation screening and CFTR activity in rectal biopsies by Ussing chamber. The first sweat test performed in the subjects was done by constant direct current; golden standard diagnosis tool. The pulsed direct current was done to compare the results with the constant direct current and the CFTR mutations and CFTR expression and function by rectal biopsies. All subjects enrolled have clinical symptoms related with CF disease. 

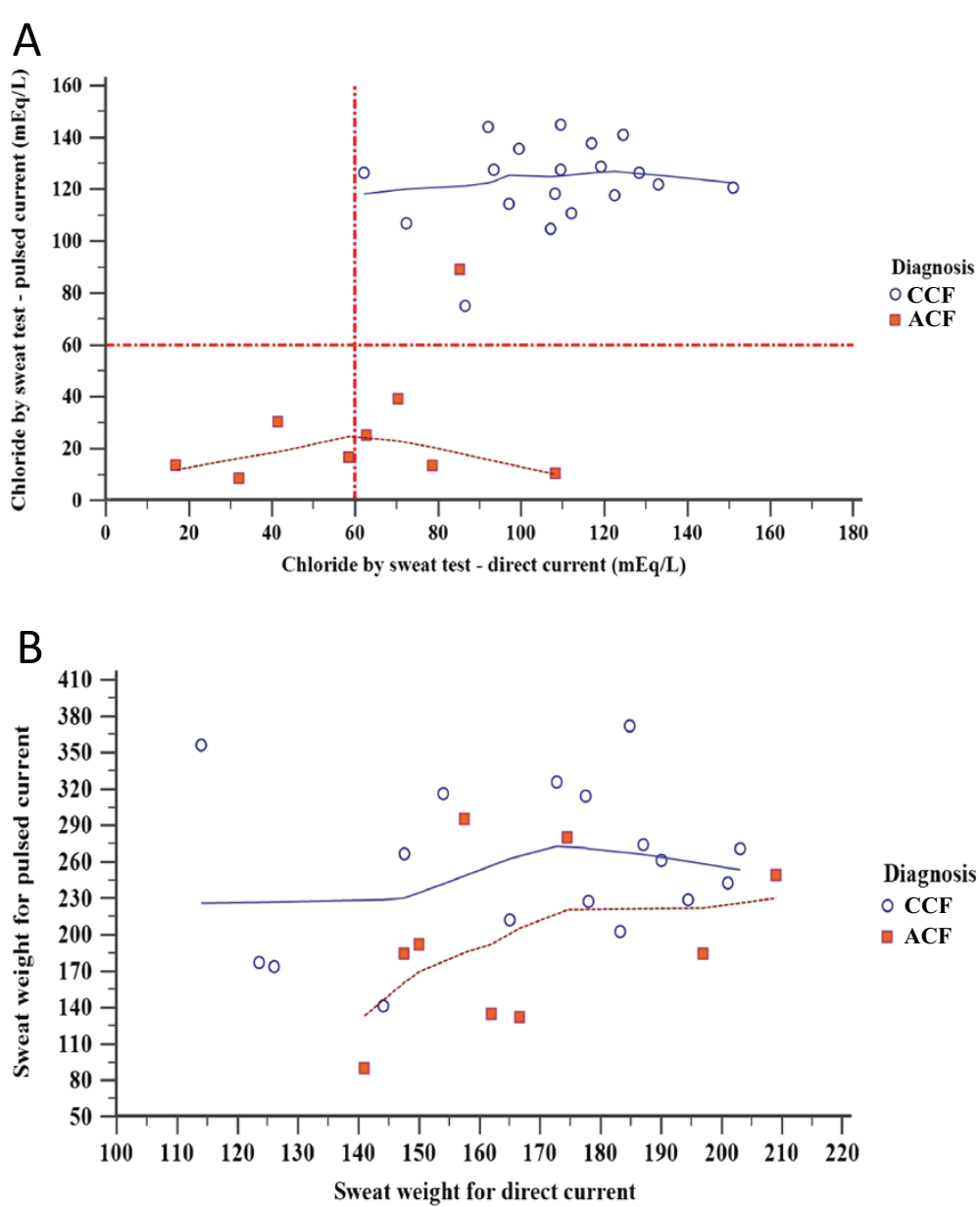

Figure 3 Pulsed direct current and constant direct current in typical and atypical cystic fibrosis (CF) patients considering the CF diagnosis and sweat weight. (A) Linear regression for chloride values ( $\mathrm{mEq} / \mathrm{L}$ ) taking into account constant direct and pulsed direct currents. In the graphic is shown the cystic fibrosis diagnosis by CFTR screening and rectal biopsy (in blue color). Twenty-eight subjects were enrolled in the study. The correlation coefficient was $0.704,95 \% \mathrm{Cl}: 0.449$ to $0.853(\mathrm{p}<0.001)$. For the same graphic there was no association between the two sweat tests performed [pulsed direct $(92.05 \pm 49.28)$ and constant direct currents $(92.80 \pm 31.84)$ ] for the values of the Chloride $(\mathrm{mEq} / \mathrm{L})(\mathrm{p}=0.911)$. Pared T-test and Spearman's correlation test $(\alpha=0.05)$ were used to study the association and correlation between variables, respectively. (B) Linear regression for sweat weight values (mg) taking into account constant direct and pulsed direct currents. The cystic fibrosis diagnosis by CFTR screening and rectal biopsy (in blue color) were shown in the graphic. Twenty-eight subjects were enrolled in the study. The correlation coefficient was $0.213,95 \% \mathrm{Cl}:-0.190$ to $0.554(p=0.296)$. For the same graphic, we observed higher values for the sweat weight on pulsed direct current $(234.86 \pm 72.49)$ than the constant direct current $(167.34 \pm 25.79)(p=0.001)$. For the association was used the test T pared and for the correlation the Spearman test. $a=0.05$. CCF, Classical Cystic Fibrosis; ACF, Atypical Cystic Fibrosis.

[40] reported that the skin impedance declined with increasing current frequencies. In our study, PDC with a frequency of $1,000 \mathrm{~Hz}$ showed lower impedance than CDC, providing adequate sweat production. Additionally, the subjects enrolled did not show high BMI, which could reduce the pilocarpine delivery and reduction of sweat production.

Electric current follows the path of minor resistance, so skin impedance determines its intensity, density and path, altering the biological responses. Skin impedance changes with the distance between electrodes, positioning, location of the electric field, amount of water and number of layers of the stratum corneum.
Keratin is the main barrier to the passage of electric current [57-63].

The interelectrode distance adopted in this study was of 2 inches and was suitable for sweat stimulation. As the ambient temperature can lead to decreased hydration of keratin and thickness of biological tissue, and thereby influence the impedance increase in skin [64], the room temperature was maintained at $25^{\circ} \mathrm{C}$.

Temperature increase at the electrode is proportional to the square of $C D$ [61]. This effect was measured on the place of the skin contact with the electrodes, before and after stimulation. The applied CD promoted cooling, and no heating of the electrodes, preventing burns. 
Our study showed that, despite the wide CST use for the CF diagnosis, there is still a field of studies to assess and maximize the efficiency and effectiveness of stimulation and collection steps. Currently, there is an increasing frequency of the CST use, especially in younger individuals, due to the implementation of CF newborn screening in our country. Therefore, we believe that the use of PDC may be a benefit for infants in the first year of life due to lower risk and discomfort associated.

\section{Conclusion}

CST with CDC or PDC using CD of 0.07 to $0.21 \mathrm{~mA} / \mathrm{cm}^{2}$ showed efficacy in stimulation and collection steps of sweat test without side effects and adequate sweat weight to perform the CST, with a greater concordance of CF diagnosis for PDC sweat test.

\section{Additional files}

\section{Additional file 1: Visual analogue scale. \\ Additional file 2: Genotypes for the CFTR mutations of typical and atypical cystic fibrosis patients enrolled in the study $(n=29)$. \\ Additional file 3: CFTR mutations found in individuals enrolled in the study. Gene and protein localization. Mutation classification and frequency from the present study are designated. Traditional and HGVs standard nomenclature for CFTR mutations are also indicated.}

\section{Abbreviations}

CDC: Constant direct current; PDC: Pulsed direct current; $\mathrm{Cl}^{-}$: Chloride; CD: Current density; VAS: Visual analogue scale; CF: Cystic fibrosis; I: Current; BMl: Body mass index; Irms: Effective measured current; J: Density; LHRH: Luteinizing-hormone-releasing hormone; MIM: Mendelian inheritance in man; S: Electrode area; CST: Classic sweat test; $\mathrm{V}_{\text {rms: }}$ Voltage; Z: Composite impedance.

\section{Competing interests}

The authors declare that they have no competing interests.

\section{Authors' contributions \\ CCSG/MFS/FALM/FUVJ/JDR - have made substantial contributions to conception and design, acquisition of data, analysis and interpretation of data; have been involved in drafting the manuscript or revising it critically for important intellectual content; and have given final approval of the version to be published. AMV/AFR/ ADCT/MAGOR - have made substantial contributions to conception and design of the study, and acquisition of clinical data. CRP/MVSSR/SLSL/ETC - have made substantial contributions to conception and design of the study, performed the technical analysis. All authors read and approved the final manuscript.}

\section{Acknowledgment}

The Pulmonary Physiology Laboratory and the Laboratory for Cystic Fibrosis by the possibility of achieving the sweat test.

The laboratory team of the Faculty of Medical Sciences, Unicamp - http:// www.laboratoriomultiusuario.com.br/ for the statistical analysis. The FAPESP for the PhD scholarship [process 2011/12939-4] for the author FALM. The Professor Carmen Silvia Bertuzzo by the screening of CFTR mutations. Taís N. Mazzola for the revision of the manuscript.

\section{Author details}

${ }^{1}$ Departament of Pediatrics, Faculty of Medical Sciences, State University of Campinas, 13083-887 Campinas, SP, Brazil. ${ }^{2}$ Centre for Research in Pediatrics (CIPED), Faculty of Medical Sciences, State University of Campinas, 13083-887 Campinas, SP, Brazil. ${ }^{3}$ Gastrocentro - Endoscopy Unit - State University of Campinas (Unicamp) - Cidade Universitária Zeferino Vaz - Barão Geraldo,
13083-872 Campinas, SP, Brazil. ${ }^{4}$ Departament of Medical Genetics, Faculty of Medical Sciences, State University of Campinas, 13083-887 Campinas, SP, Brazil. ${ }^{5}$ Center for Biomedical Engineering (CEB), State University of Campinas, 13083-970 Campinas, SP, Brazil. 'Department of Biomedical Engineering, Faculty of Electrical and Computer Engineering, University of Campinas, 13083-881 Campinas, SP, Brazil. ${ }^{7}$ Federal Institute of Education, Science and Technology of Sao Paulo (IFSP), Campus Campinas, 13069-901, km 143,5, Campinas, SP, Brazil.

Received: 18 June 2014 Accepted: 27 November 2014

Published: 13 December 2014

\section{References}

1. Di Sant'S Agnese PA, Darling RC, Perara GA, Shea E: Abnormal electrolyte composition of sweat in cystic fibrosis of the pancreas. Am J Dis Child 1953, 86(Suppl 5):618-619.

2. Gibson LE, Cooke RE: A test for concentration of electrolytes in sweat in cystic fibrosis of the pancreas utilizing pilocarpine by iontophoresis. Pediatrics 1959, 23(Suppl 3):545-549.

3. Taylor CJ, Hardcastle J, Southern KW: Physiological measurements confirming the diagnosis of cystic fibrosis. The sweat test and measurements of transepithelial potential difference. Paedia Resp Rev 2009, 10:220-226.

4. Rosenstein BJ: What is a cystic fibrosis diagnosis? Clin Chest Med 1998, 19(Suppl 3):423-441.

5. Rowe SM, Miller S, Sorscher EJ: Cystic fibrosis. N Engl J Med 2005, 352(Suppl 19):1992-2001.

6. Farrell PM, Rosenstein BJ, White TB, Accurso FJ, Castellani C, Cutting GR, Durie PR, Legrys VA, Massie J, Parad RB, Rock MJ, Campbell PW 3rd, Cystic Fibrosis Foundation: Guidelines for diagnosis of cystic fibrosis in newborns through older adults: Cystic Fibrosis Foundation Consensus Report. J Pediatr 2008, 153:S4-e14.

7. Castellani C, Southern KW, Brownlee K, DankertRoelse J, Duff A, Farrell M, Mehta A, Munck A, Pollitt R, Sermet-Gaudelus I, Wilcken B, Ballmann M, Corbetta C, de Monestrol I, Farrell P, Feilcke M, Férec C, Gartner S, Gaskin K, Hammermann J, Kashirskaya N, Loeber G, Macek M Jr, Mehta G, Reiman A, Rizzotti P, Sammon A, Sands D, Smyth A, Sommerburg O, Torresani T, Travert G, Vernooij A, Elborn S: European best practice guidelines for cystic fibrosis neonatal screening. J Cystic Fibrosis 2009, 8:153-173.

8. Quinton PM: Cystic fibrosis: lesson from the sweat gland. Physiology (Bethesda) 2007, 22:212-225.

9. Quinton PM: Chloride impermeability in cystic fibrosis. Nature 1983, 301:421-422.

10. Collie JTB, Massie RJ, Jones OAH, LeGrys VA, Greaves RF: Sixty-Five Years Since the New York Heat Wave: Advances in Sweat Testing for Cystic Fibrosis. Pediatr Pulmonol 2014, 49:106-117.

11. Legrys VA: Sweat testing for the diagnosis of cystic fibrosis. Practical considerations. J Pedia 1996, 129(Suppl 6):892-897.

12. Gonçalves AC, Marson FAL, Mendonça RMH, Ribeiro JD, Ribeiro AF, Paschoal IA, Levy CE: Saliva as a potential tool for cystic fibrosisdiagnosis. Diagn Pathol 2013, 8:46.

13. Webster $\mathrm{HL}$ : A clinical appraisal of cystic fibrosis sweat-testing guidelines. Am Clin Lab 2001, 20:39-42.

14. Hammond KB, Nelson L, Gibson LE: Clinical evaluation of the macroduct sweat collection system and conductivity analyzer in the diagnosis of cystic fibrosis. J Pediatr 1994, 124:255-260.

15. Brasil. Portaria N²88, 21 de Março de 2013.. Diário oficial da união, Brasília, Nº 56 - DOU - 22/03/13 - seção 1 - p.47. Disponível em URL: ftp://ftp. saude.sp.gov.br/ftpsessp/bibliote/informe_eletronico/2013/iels.mar.13/lels55/ U_PT-MS-SAS-288_210313.pdf.

16. Numajiri S, Sakurai H, Sugibayashi K, Morimoto Y, Omiya H, Takenaka H, Akiyama N: Comparison of depolarizing and direct current systems on iontophoretic enhancement of transport of sodium benzoate through human and hairless rat skin. J Pharm Pharmcol 1993, 45:610-613.

17. Zakzewski CA, Amory DW, Jasaitis DK, Li JKJ: lontophoretically enhanced transdermal delivery of an ACE inhibitor in induced hypertensive rabbits: preliminary report. CardiovascularDrugs and Therapy 1992, 6(Suppl 6):589-595.

18. Bagniefski TM, Burnette RR: A comparison of pulsed and continuous current iontophoresis. J Cont Release 1990, II:113-122. 
19. Preat $\mathrm{V}$, Thysman S: Trandermaliontophoreric delivery of sulfentanillnt. J Pharmaceut 1993, 96:189-196.

20. WHO: Obesity: Preventing and managing the global epidemic. Geneva: World Health Organization Technical Support Series, 894. Geneva: World Health Organization; 2000.

21. Sousa M, Servidoni MF, Vinagre AM, Ramalho AS, Bonadia LC, Felício V, Ribeiro MA, Uliyakina I, Marson FA, Kmit A, Cardoso SR, Ribeiro JD, Bertuzzo CS, Sousa L, Kunzelmann K, Ribeiro AF, Amaral MD: Measurements of CFTR-mediated $\mathrm{Cl}$ - secretion in human rectal biopsies constitute a robust biomarker for Cystic Fibrosis diagnosis and prognosis. Plos One 2012, 7(Suppl 10):e47708.

22. Carlsson AM: Assessment of chronic pain . I. Aspects of the reliability and validity of the visual analogue scale. Pain 1983, 16(Suppl 1):87-101.

23. Rosenstein BJ, Cutting GR: The diagnosis of cystic fibrosis: a consensus statement. Cystic Fibrosis Foundation Consensus Panel. J Pediatr 1998 132(Suppl 4):589-595.

24. Karezeski B, Cutting G: Diagnosis of cystic fibrosis. CFTR-related disease and screening. ProgRespir Res 2006, 34:69-76.

25. Strausbaugh SD, Davis PB: Cystic fibrosis: a review of epidemiology and pathobiology. Clin Chest Med 2007, 28(Suppl 2):279-288.

26. Mackay R, George P, Kirk J: Sweat testing for cystic fibrosis: A review of New Zealand laboratories. J Paedia Child Health 2006, 42:160-164.

27. Cirilli N, Podan R, Raia V: Audit of sweat testing: A first report from Italian cystic fibrosis centres. J Cystic Fibrosis 2008, 7:415-422.

28. Kirk JM: Inconsistencies in sweat testing in UK laboratories. Arch Dis Child 2000, 82:425-427.

29. Webster HL: Laboratory diagnosis of cystic fibrosis. CRC Crit Rev in Clin LabSci 1983, 18:313-338.

30. Wescor Inc. http://www.wescor.com/biomedical/cysticfibrosis/macroduct. html.

31. Sabbahi MA, Costello CT, Ernran A: A method for reducing skin irritation by iontophoresis. PhysTher 1994, 74:S156.

32. Su MH, Srinivasan V, Ghanem AH, Higuchi Wl: Quantitative in vivo iontophoreticstudies. J Pharm Sci 1994, 83:12-17.

33. Huang Y-Y, Wu S-M: Transdermal lontophoretic Delivery of ThyrotropinReleasing Hormone Across Excised Rabbit Pinna Skin Drug Dev. Ind Pharm 1996, 22(Suppl 11):1075-1081.

34. Knoblauch P, Moll F: In vitro pulsatile and continuous transdermal delivery of buserelin by iontophoresis. J Control Release 1993, 26(Suppl 3):203-212.

35. Okabe K, Yamaguchi H, Kawai Y: New iontophoretic transdermal administration of the beta-blocker metoprolol. J Control Release 1986, 4:79-85.

36. Li SK, Higuchi WI, Zhu H, Kern SE, Miller DJ, Hastings MS: In vitro and in vivo comparisons of constant resistance $A C$ iontophoresis and $D C$ iontophoresis. J Control Release 2003, 91:327-343.

37. Banga AK, Chien YW: lontophoretic delivery of drugs: fundamentals, developments and biomedical application. J Control Rel 1988, 7:1.

38. Panzade P, Heda A, Puranik P, Patni M, Mogal V: Enhanced Transdermal Delivery of Granisetron by Using lontophoresis. IJPR 2012 11(Suppl 2):503-512.

39. Chen LLH, Chien YW: Transdermal iontophoretic permeation of luteinizing hormone releasing hormone: characterization of electric parameters. J Control Release 1996, 40:187-198.

40. Chien YW, Siddiqui O, Shi WM, Lelawongs P, Liu JC: Direct current iontophoretic transdermal delivery of peptide and protein drugs. J Pharm Sci 1989, 78:376-383.

41. Hirvonen J, Hueber F, Guy RH: Current profile regulates iontophoretic delivery of amino acids across the skin. J Control Release 1995, 37:239-249.

42. Kanebako M, Inagi T, Takayama K: Transdermal delivery of iondomethacin by iontophoresis. Biol Pharm Bull 2002, 25:779-782.

43. Abramowitz D, Neoussikine B: Treatment by Ion Transfer. NewYork: Grune and Stratton; 1946:87.

44. LeGrys VA, Applequist R, Briscoe DR, Farrell P, Hickstein R, Lo SF, Passarell R, Rheinheiner DW, Rosenstein BJ, Vaks JE: Sweat testing: sample collection and quantitative chloride analysis; approved guidelines - Third Edition. Clin Lab Stand Ins 2009, 29(Suppl 27):C34-A2.

45. Beauchamp M, Lands LC: Sweat-Testing: A Review of Current Technical Requirements. Pediatr Pulmonol 2005, 39:507-511.

46. Chiang $\mathrm{CH}$, Shao $\mathrm{CH}$, Chen JL: Effects of pH electric current, and enzyme inhibitors on iontophoresis of delta sleep-inducing peptide. Drug Dev Ind Pharm 1998, 24:431-438.
47. Van der Geest R, Banhof M, Bodde HE: Iontophoretic delivery of apomorphine I. In-vitro optimization and validation. Pharm Res 1997, 14:1798-1803

48. Heap S: Guidelines for the Performance of the Sweat Test for the Investigation of Cystic Fibrosis in the UK 2nd Version. An Evidence Based Guideline. R College Paediatr Child Health 2014, 2:1-121.

49. Kalia YN, Naik A, Garrison J, Guy RH: Iontophoretic drug delivery. Adv Drug Deliver 2004, 56(Suppl 5):619-658.

50. Barry BW: Drug delivery routes in skin: a novel approach. Adv Drug Deliv Rev 2002, 54:S31-S40.

51. Pikal MJ: The role of electroosmotic flow in transdermal iontophoresis. Adv Drug Deliv Rev 1992, 9:201-237.

52. Curdy C, Kalia YN, Guy RH: Post-iontophoresis recovery of human skin impedance in vivo. Eur J Pharm Biopharm 2002, 53:15-21.

53. Ulreich A, Leibrecht W, Promer M, Kullich W: Infiltration versus iontophoresis in case of epicondylitis. A comparative study. Physikalische Medizin Rehabilitations medizin. Kurortmedizin 1996, 6:183-185.

54. Bolfe VJ, Ribas SI, Montebelo MIL, Guirro RRJ: Comportamento da impedância elétrica dos tecidos biológicos durante a estimulação elétrica transcutânea. Rev Bras Fisioter 2007, 11(Suppl 2):153-159.

55. Kyle UG, Bosaeus I, De Lorenzo AD, Deurenberg P, Elia M, Gómez JM, Heitmann BL, Kent-Smith L, Melchior JC, Pirlich M, Scharfetter H, Schols AM, Pichard C, Composition of the ESPEN Working Group: Bioelectrical impedance analysis-part I: review of principles and methods. ClinNutr 2004, 23(Suppl 5):1226-1243.

56. Nakakura M, Kato Y, Hayakawa E, Kuroda T: Effect of pulse on iontophoretic delivery of desmopressin acetate in rats. Biol Pharm Bull 1996, 19:738-740.

57. Sagi-Dolev AM, Prutchi D, Nathan RH: Three-dimensional current density distribuition under surface stimulation electrodes. Med Biol Eng Comp 1995, 33:403-408

58. Zhu F, Scheditz D, Levin NW: Estimation of trunk extracellular volume by bioimpedance. Conf Proc IEEE Eng Med Biol Soc 1998, 20(Suppl 6):3104-3107.

59. Chizmadzhev YA, Kuzmin PI, Weaver JC, Potts RO: Skin appendageal macropores as a possible pat way for electrical current. J Investg Dermatol Symp Proc 1998, 3(2):148-152.

60. Ya-Xian, Suetake T, Tagami H: Number of cell layers of the stratum corneum in normal skin-relationship to the anatomical location on the body, age, sex and physical parameters. Arch Dermatol Res 1999, 291:555-559.

61. Nelson RM, Hayes KW, Currier DP: Clinical Electrotherapy.3a. ed. Stanford: Appleton \& Lange; 1999:15-54.

62. Low J, Reed A: Electrotherapy Explained: Principles and Practice. Oxford: Butterworth-Heinemann; 2000.

63. Cameron MH: Physical Agents in Rehabilitation: From Research to Practice. Philadelphia: W.B.Saunders company; 1999

64. Kubisz $\mathrm{L}:$ The influence of storage time on the temperature dependence of the dc electrical conductivity of horn kereatin. Bioelectrochemistry 2001, 53(Suppl 2):161-164.

doi:10.1186/1471-2466-14-198

Cite this article as: Gomez et al:: Pulsed direct and constant direct currents in the pilocarpine iontophoresis sweat chloride test. BMC Pulmonary Medicine 2014 14:198.

\section{Submit your next manuscript to BioMed Central and take full advantage of:}

- Convenient online submission

- Thorough peer review

- No space constraints or color figure charges

- Immediate publication on acceptance

- Inclusion in PubMed, CAS, Scopus and Google Scholar

- Research which is freely available for redistribution 